\title{
Analysis of Factors That Influence Financial Statement Fraud In The Perspective Fraud Triangle: Empirical Study on Banking Companies In Indonesia
}

\author{
Rudy Hartanto ${ }^{1}$, Lasmanah ${ }^{2}$, Muhammad Ridwan Mustafa ${ }^{3}$, Pupung Purnamasari ${ }^{4}$ \\ \{rudyhartanto05@gmail.com ${ }^{1}$, lasmanah.ina@gmail.com², ridwanmaksi42@gmail.com ${ }^{3}$, \\ p_purnamasari@yahoo.co.id $\left.{ }^{4}\right\}$ \\ 1,2,3,4Fakultas Ekonomi dan Bisnis Universitas Islam Bandung, Jl. Tamansari 1 Bandung, Indonesia
}

\begin{abstract}
The purpose of this study is to explain the factors that influence fraudulent financial statements in Indonesian banks. This research takes the banking sector into consideration that banking is one of the industries or the most vulnerable institutions for financial incidents due to the many regulations and financial transactions that occur in the banking sector. This study uses banking data from 2014-2017 with a total sample of 90 banks. Data analysis techniques are carried out using multiple regression analysis. The results show that the pressure proxied by external pressure, which is proxied by free cash flow, has a positive effect on fraudulent financial statements, which means that the greater the free cash flow of the banking sector, the greater the likelihood of fraudulent financial statements. Whereas pressure proxied by financial stability, financial targets, and ineffective monitoring and rationalization and good governance have no effect on fraudulent financial statements.
\end{abstract}

Keywords: Financial Statement Fraud, Banking, Good Governance, Fraud Triangle Theory

\section{Introduction}

Today, fraud is a common thing in the financial and non-financial industries. Fraud in the financial industry is usually regarded as a fraud of financial statements. Fraud of financial statements is a behavior that is intentionally or unintentionally carried out with harmful material carried out by manipulating and deceiving financial [1]. The losses caused by fraudulent financial statements reached a value of $\$ 6.3$ billion dollars worldwide (ACFE, 2017).

Kingsley (2012) stated that the industry or institution that is most vulnerable to fraud is banking industry. This vulnerability could be seen from the very strict report regulations on each transaction that is happened in banking [2][3]. Based on the Financial Services Authority's (OJK) report, there was an increase in fraud case reports from 23 cases in 2015 to 26 cases in 2016 [4]. In 2018, according to the Financial Transaction Reports and Analysis Center's (PPATK) report in the figure below, it could be seen that banking is the largest contributor to the Suspicious Financial Transaction Report (LTKM), which were 214.389 reports or $52 \%$ of the total reports (PPATK, 2018). 


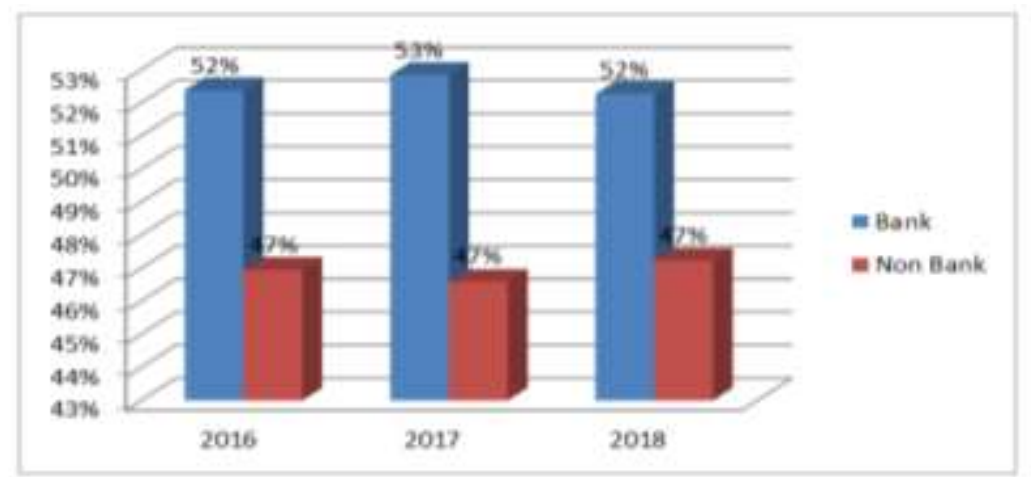

Fig.1. Percentage of Number of Suspicious Financial Transaction Reports Source: PPATK, 2018

Fraud that occurred in the banking sector showed that the banking internal control itself was still weak. The weak of internal control showed that there was still a lack of good governance run by banks. In the past 10 years, the good banking governance value has decreased (LPPI, 2018; Hartanto and Purnamasari, 2019). The poor of good banking governance can indicate an indication of a relationship with the proliferation of fraudulent funds or the practice of fraud. In order to avoid the large losses that occured due to fraudulent financial statements, it is necessary to do empirical studies related to steps to predict and detect fraudulent financial statements. By incorporating GCG as a proxy in the detection of fraudulent financial statements, a comprehensive picture will be found regarding the factors causing fraudulent financial statements. A financial transaction that occurs in banking is carried out with the smallest trust, security and risk [5]. One of the method to increase the trust, security and risk arising from financial transactions is to minimize the losses incurred due to fraud. Preventing and detecting of fraud will have a direct impact on the application of safe and healthy banking practices[6][7]. In this regard, fraud will be known by considering the context of the theory of fraud triangle which consists of pressure, opportunity, and rationalization [8]. In addition, the best GCG implementation will also reduce the level of fraud that [9]. Based on this urgency, it is important for banking to detect fraud in order to avoid the losses.

\section{Literature Review}

\subsection{Financial Statement Fraud}

Financial Statement Fraud (FSF)[10]-[14] is a type of fraud that is interpreted as a behavior taken to cover up the actual of financial statements by manipulating either carried out by officials or executives of a company or government agency in order to obtain the profits (ACFE, 2017). Fraud is specifically according to the theory stated by Cressey (1953) which is called the Fraud Triangle caused by incentive/pressure, opportunity and rationalization. Incentive/pressure related to the need to commit fraud that can include the lifestyle, economic demands, and other matters relating to finance or non-finance. Opportunity is related to opportunities that cause someone to do the fraud. While rationalization is related to the character of someone or other parties to state justification for fraud. 


\subsection{Earning Management}

One of the method to manipulate financial statements is to do earnings management that can provide personal benefits [15]. Earnings management can be done by controlling accrual transactions that occur in the company [16]. Accrual transactions are types of transactions that do not affect the cash such as the recognition of corporate debt and receivables or changes in accounting policies. Manipulation through changes in accounting policies or called dicretionary accruals is manipulation that is difficult to detect. According to the study of Utami (2005) and Susanti (2014), calculations are performed to calculate earnings management through dicretionary accruals by calculating working capital accruals. Accrual working capital is calculated from the cash flow statement of investment activities. Perols and Lougee's research (2011) shows that measurement of discretionary accruals shows evidence of predicting fraud that is better than other measures of fraudulent financial statements.

\subsection{Development of Hypotheses}

The development of the hypothesis in this study is explained in the picture below:

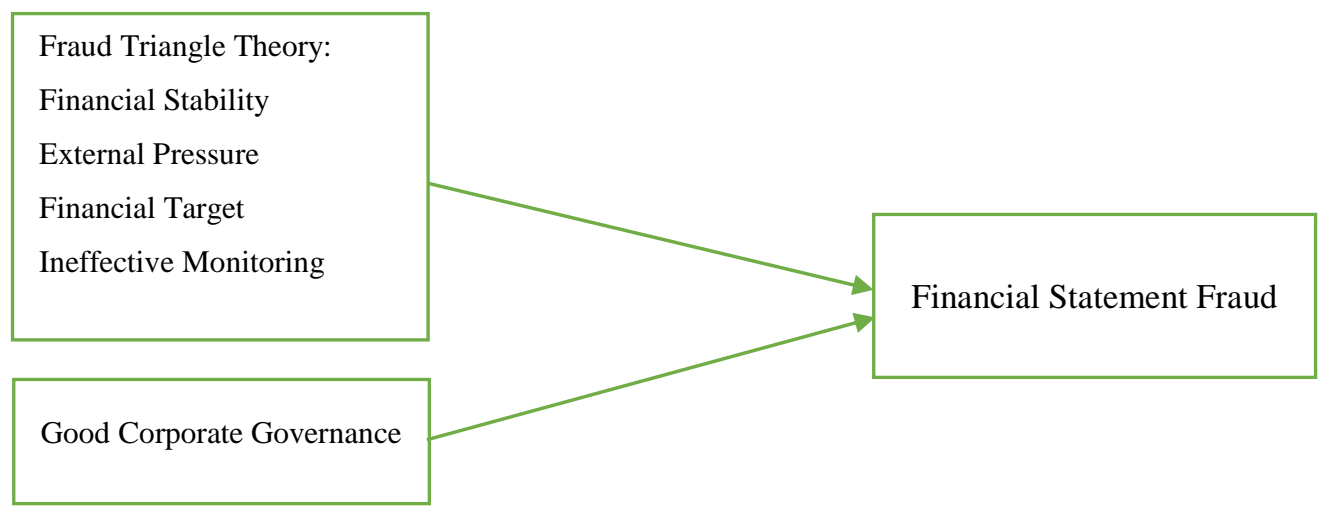

Fig. 2. Development of Hypotheses

\section{Research Methods}

\subsection{Population and Samples}

The data used in this study is a secondary data, in the form of banking financial statements for year 2014-2017. The sampling method in this study used purposive sampling. The sampling criteria are as follows:

Table 1. Sampling Criteria

\begin{tabular}{clc}
\hline No & Criteria & Total \\
\hline 1 & Number of Banking in 2014-2017 (115 banks @ 4 years) & 460 \\
\hline 2 & Do not have complete data in supporting variables & $(370)$ \\
\hline & Total Samples (2014-2017) & 90 \\
\hline
\end{tabular}

Source: data processed, 2019 


\subsection{Definition of Operational Variables}

Table 2. Definition of Operational Variables

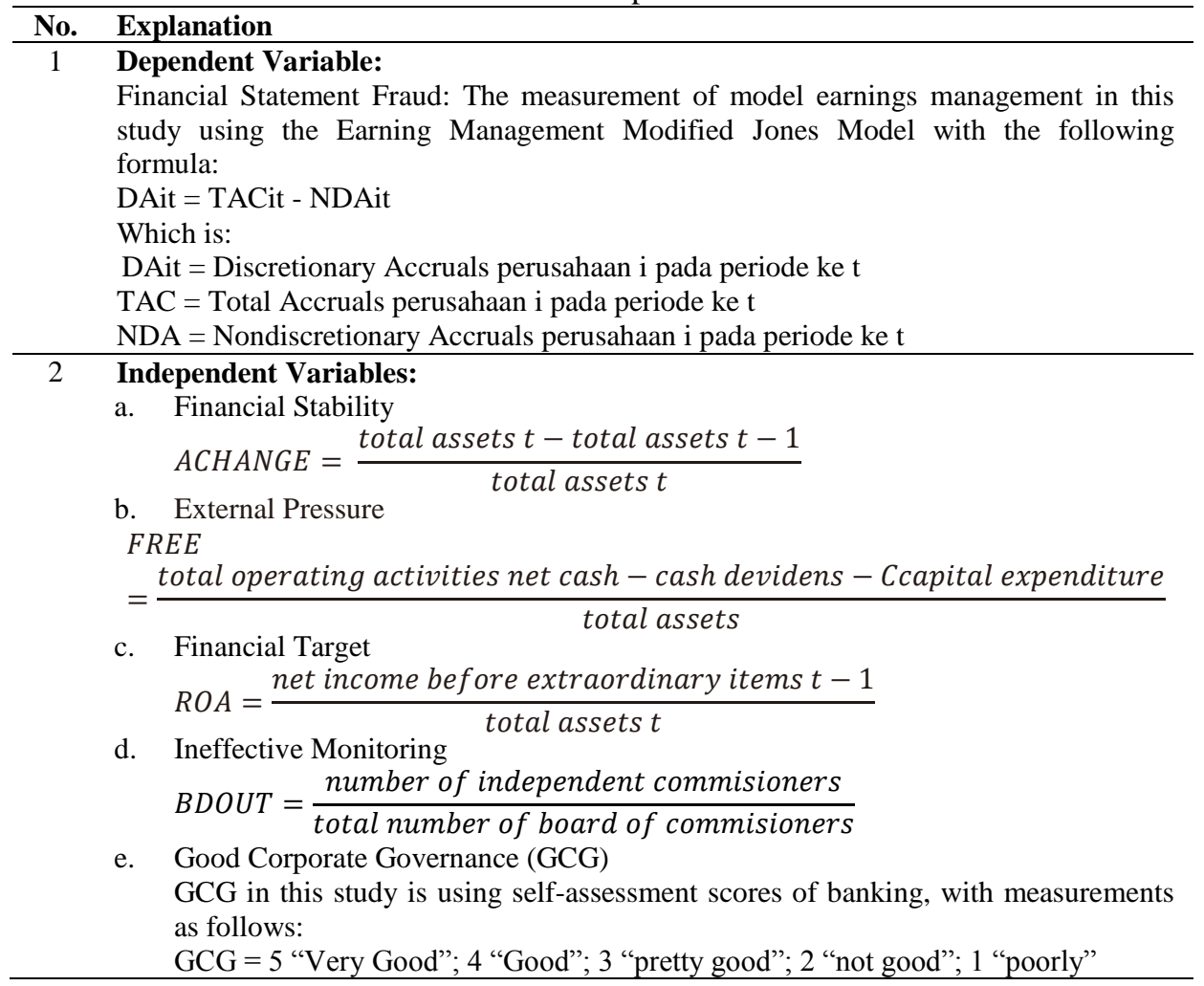

\section{Research Results}

Descriptive statistics found in the table below show the results that the average value of Fraud Financial Statement (FSF) is 0.41 which can mean that most banks have values below 1 which indicates that very few banks do fraudulent financial statements measured using earnings management. The value of net cash flow (FREEC) shows that the average free cash flow of banks is approximately 3 trillion. However, if viewed from the minimum value of FREEC, there are banks that have a cash flow value of minus 14 trillion. Financial Target (FT) value which is calculated by the return on assets value if seen the minimum minus value can be interpreted that there are still banks that have not been able to make good use of assets owned to generate profits. If you see the value of the percentage of independent commissioners (BDOUT) both from the minimum, maximum, and mean values it can be seen that the percentage of BDOUT is close to $40 \%$ and above which can be interpreted that almost all banks have a percentage of independent commissioners with a greater proportion of all commissioners independent owned. In addition, banks also have good governance when viewed from the value of banking governance (GCG) with an average of 3.7 where values above 3 can be interpreted well. 
Table 3. Descriptive Statistics

\begin{tabular}{|c|c|c|c|c|}
\hline Variable & $\mathbf{N}$ & Minimum & Maximum & Mean \\
\hline FSF & 90 & 0 & 1 & 0,411 \\
\hline FREEC (in million) & 90 & -13.521 .915 & 4.0744 .683 & 3.248 .255 \\
\hline FT & 90 & $-5,37 \%$ & $4,34 \%$ & $1,86 \%$ \\
\hline BDOUT & 90 & $42,9 \%$ & $80 \%$ & $57,25 \%$ \\
\hline GCG & 90 & 2 & 5 & 3,7 \\
\hline
\end{tabular}

After descriptive analysis, the next step in this research is to do a multiple regression test to see what factors influence the financial statement of banking fraud in Indonesia. Multiple regression testing in this study has been tested using classical assumptions to see the feasibility of the model. The following are presented in the results of multiple regression analysis in this study:

Table 4. Multiple Regression Analysis

\begin{tabular}{llcccc}
\hline \multirow{2}{*}{ Model } & T & Sig. & \multicolumn{2}{c}{ Collinearity Statistics } \\
\cline { 3 - 6 } & & & & Tolerance & VIF \\
\hline & (Constant) & 0,365 & 0,716 & & \\
\cline { 2 - 6 } & ACHANGE & $-1,432$ & 0,156 & 0,845 & 1,183 \\
\cline { 2 - 6 } & FREEC & $-2,702$ & $0,008^{*}$ & 0,895 & 1,117 \\
\cline { 2 - 6 } & FT & 1,352 & 0,180 & 0,901 & 1,110 \\
\cline { 2 - 6 } & BDOUT & 0,208 & 0,836 & 0,957 & 1,045 \\
\cline { 2 - 6 } & GCG & $-0,164$ & 0,870 & 0,943 & 1,061 \\
\hline R Square & $\left(\mathrm{R}^{2}\right) \quad=0,129 / 12,9 \%$ & & \\
$*$ &
\end{tabular}

Based on the results of multiple regression analysis in table 4.2 above, it can be explained about the test results as follows:

a) The results of the coefficient of determination (R2) for discretionary accruals are 0.129 (12.9\%). This means that $12.9 \%$ of discretionary accrual variations in banking companies can be explained by variations of the independent variables in this study. While the remaining $87.1 \%$ is discussed by other factors beyond this research variable.

b) Free cash flow variable (FREEC) shows the value of sig. $<0.05$ which is equal to 0.008 with a value of -2.702 which means a negative value for financial statement fraud. This means that the higher the company's free cash flow, the lower the company conducts financial statement fraud. This is consistent with the research conducted by Skousen et al (2009)

c) Financial Target Variables (FT), Percentage of Independent Commissioners (BDOUT) and Good Corporate Governance (GCG). > 0.05, which means that this variable does not show an effect on fraud of financial statements.

\section{Conclusions}

The results of the study show that the pressure proxied by the external pressure which is proxied by free cash flow shows a negative effect on fraudulent financial statements, which means that the greater the free cash flow of banks, the less likely the occurrence of fraudulent financial statements. Whereas, pressure proxied by financial stability, financial targets, and 
ineffective monitoring and rationalization and good governance have no effect on fraudulent financial statements.

\section{References}

[1] Ismiyanti, F., \& Prastichia, C. (2015). Mekanisme Corporate Governance dan Kecurangan Laporan Keuangan. Derema Manajemen, 10(2).

[2] Associationof Certified Fraud Examiners Indonesia Chapter \#111. (2017). Survai Fraud Indonesia 2016. Jakarta: ACFE Indonesia Chapter.

[3] Kingsley, A. (2012). Frauds In Nigerian Banks: Nature, Deep-Seated Causes, Aftermaths And Probable Remedies, 3(May), 279-290.

[4] Ariyanti, Fiki. 2016. Dalam 2 Tahun ada 108 Kasus Kejahatan Perbankan (online), (https://www.liputan6.com/bisnis/read/2651413/dalam-2-tahun-ada-108-kasuskejahatan-perbankan, diakse 20 Desember 2018).

[5] Pusat Pelaporan dan Analisis Transaksi Keuangan. (2018). Buletin Statistik Anti Pencucian Uang dan Pendanaan Terorisme, Vol 103/ Thn IX/2018. Jakarta: PPATK.

[6] LPPI. 2018. Praktik GCG Makin Menurun di Industri Perbankan (online), (https://www.wartaekonomi.co.id/read189353/praktik-gcg-makin-menurun-di-industriperbankan.html, diakses, 20 Desember 2018)

[7] Hartanto and Purnamasari. 2019. The Analysis of Banking Governance in Indonesia: the Financial Services Authority Perspective. ACCRUALS, 3(1), 32-48.

[8] Turner, J. L., T. J. Mock, R. P. Sripastava. (2003).An Analysis of the Fraud Triangle. The University of Memphis,University of Southern California,University of Kansas.

[9] Chen, Gongmeng., Michael F.Daniel N.G, dan Oliver M.Rui. (2005). Ownership Structure, Corporate Governance, and Fraud: Evidence From China. Journal of Corporate Finance, 12, 424-448.

[10] Zhang, Yi and Guang Ma. (2005). Law, Economic, Corporate Governnace, and Corporate Scandal in a Transition Economy: Insight from China.Guanghua School of Management.

[11] Cressey, D. R. (1953). Other People's Money. Montclair, NJ: Patterson Smith, 1-300.

[12] Skousen, C.J., K. R. Smith, dan C.J Wright. (2008). Detecting and Predecting Financial Statement Fraud: The Effectiveness of The Fraud Triangle and SAS No. 99. Corporate Governance and Firm Performance Advances in Financial Economis, 13, 1-39.

[13] Schipper, K., 1989. Earnings Management. Accounting Horizons, 3(4), 91-102.

[14] Susanti. 2014. Pendeteksian Kecurangan Laporan Keuangan dengan Analisis Fraud Triangle. Skripsi. Program Sarjana, Program Studi Akuntansi, Universitas Airlangga Surabaya.

[15] Utami. 2005.Pengaruh Manajemen Laba Terhadap Biaya Modal Ekuitas (Studi Pada Perusahaan Publik Sektor Manufaktur).Makalah dipresentasikan dalam Simposium Nasional Akuntansi (SNA) VII Universitas Sebelas Maret, Solo, 15-16 September.

[16] Perols dan Lougee. 2011. The Relation Between Earnings Management and Financial Statement Fraud.Advance in Accounting, 27(1), 39-53. 